\title{
Inhibition of Antigen- and Mitogen-Induced Human Lymphocyte Proliferation by Gold Compounds
}

\author{
Peter E. Lipsky and Morris Ziff \\ From the Rheumatic Diseases Unit, Department of Internal Medicine, The University of Texas \\ Southwestern Medical School, Dallas, Texas 7.523.5
}

A B S T RACT Gold sodium thiomalate (GST) inhibited in vitro antigen- and mitogen-triggered human lymphocyte DNA synthesis. Inhibition of responsiveness was observed with concentrations of GST equivalent to gold levels found in serum or tissues of patients receiving chrysotherapy. Inhibition was dependent upon the gold ion itself since GST and gold chloride were both inhibitory whereas thiomalic acid was not. Inhibition could not be explained by nonspecific killing of cells or by an alteration in the kinetics of the responses. GST inhibited mitogeninduced proliferation most effectively when present from the initiation of culture and could not inhibit the responsiveness of cells which previously had been activated by concanavalin $\mathrm{A}$. These findings indicated that GST blocked a critical early step in lymphocyte activation. The degree of GST-induced inhibition of proliferation was increased in cultures of cells partially depleted of monocytes. Moreover, inhibition was reversed by supplementation of these cultures with purified monocytes. These observations suggested that GST blocked thymus-derived (T)lymphocyte activation by interfering with a requisite function of the monocyte population in initiating such responses. Prolonged incubation of peripheral blood mononuclear cells with GST resulted in diminished mitogen responsiveness upon subsequent culture in the absence of gold. The addition of fresh monocytes restored responsiveness to these populations. Furthermore, preincubation of purified monocytes with GST rendered them deficient in their ability to support mitogen-induced T-lymphocyte proliferation

This work was presented in part at the Annual Scientific Meeting of the American Rheumatism Association, Chicago, Ill., 11 June 1976.

Dr. Lipsky is a recipient of a Postdoctoral Fellowship from the Arthritis Foundation. Dr. Ziff is a recipient of a U. S. Public Health Service Research Career Award.

Received for publication 30 August 1976 and in revised form 15 November 1976. on subsequent culture. These observations indicate that the major effect of GST results from interference with the functional capability of the monocyte population.

\section{INTRODUCTION}

Rheumatoid arthritis is a disease characterized by chronic inflammation of synovial tissues. Although its etiology remains unknown, immunological processes have been implicated in the pathogenesis and maintenance of the chronic synovitis (1). Thus, cells of bone marrow origin, along with their secretory products, play a role in this process as indicated by the presence, within rheumatoid synovial tissue, of cells which synthesize and secrete both immunoglobulin and rheumatoid factor locally $(2-4)$. More recently, a role for thymus-derived $(\mathrm{T})^{1}$ lymphocytes also has been suggested by the demonstration of large numbers of $\mathrm{T}$ lymphocytes as compared to bone-marrow derived lymphocytes (B lymphocytes), both in synovial fluid (5-7) and digests of synovial tissue $(8,9)$.

Chrysotherapy has been used in the treatment of rheumatoid arthritis for nearly 50 years. Recent clinical trials have established that treatment with gold compounds not only can ameliorate the symptoms of rheumatoid arthritis, but also can slow or even halt the progress of the disease $(10-13)$. These observations imply that gold compounds exert a potent antiinflammatory effect in vivo. Since immune mechanisms

\footnotetext{
${ }^{1}$ Abbreviations used in this paper: B lymphocyte (or B cell), bone-marrow derived lymphocyte; Con A, concanavalin A; $\Delta c p m$, difference in counts per minute between the means of triplicate-stimulated and control cultures; FBS, fetal bovine serum; GST, gold sodium thiomalate; 2-ME, 2-mercaptoethanol; MLR, mixed leukocyte reaction; $M \Phi$, monocyte or macrophage; PBL, peripheral blood lymphocyte depleted of adherent cells; PBM, peripheral blood mononuclear cell; PHA, phytohemagglutinin; PWM, pokeweed mitogen; SK/SD, streptokinase-streptodornase; T lymphocyte (or T cell), thymus-derived lymphocyte; TMA, thiomalic acid.
} 
are thought to mediate the chronic inflammatory synovitis of rheumatoid arthritis, it seems reasonable to suggest that the therapeutic efficacy of gold compounds may relate to their ability to modify immunological processes.

The studies reported here were undertaken, therefore, to delineate the effect of gold compounds on certain in vitro correlates of immune responsiveness. Specifically, the action of gold sodium thiomalate (GST) has been investigated, with respect to its ability to modify in vitro antigen- and mitogeninduced proliferative responses in populations of normal human peripheral blood mononuclear cells. These proliferative responses share two characteristics. First, the primary responding cells are T lymphocytes (14-16), and, second, the initiation of each of these responses is dependent upon the active participation of a nonresponding accessory cell (17-22). In populations of human peripheral blood mononuclear cells, the monocyte subserves this function $(15,18$, 19, 21, 22).

GST inhibited antigen- and mitogen-induced human lymphocyte proliferation. Inhibition, which was mediated by the gold moiety itself and not the sulfurcontaining ligand, was concentration dependent and demonstrable within the range of serum or tissue levels found in patients treated with gold compounds. Two major effects of GST were observed. The first was a reversible interference with lymphocyte activation which required the presence of the gold compound in the culture medium. The second was an irreversible diminution in the magnitude of responsiveness which developed after prolonged exposure to GST, but no longer required the presence of the gold compound in the culture to be manifest. Data are presented to indicate that neither effect resulted from an action of GST on the potential responsiveness of the lymphocyte population per se. Rather, in both cases, GST interfered with the ability of monocytes to serve as effective accessory cells in the initiation of these proliferative responses.

\section{METHODS}

Cell preparation. Venous blood was obtained from healthy young adults who were taking no medications at the time of study. The mononuclear cell population was obtained from heparinized whole blood by centrifugation on sodium metrizoate/Ficoll cushions (Lymphoprep, Nyegaard \& Co., Oslo, Norway) as previously described (23). Resultant preparations of peripheral blood mononuclear cells (PBM) consisted of 70-85\% lymphocytes and $15-30 \%$ monocytes.

Mitogens and antigens. The following stimuli were used: concanavalin A (Con A, ICN Nutritional Biochemicals Div., International Chemical \& Nuclear Corp. Cleveland, Ohio), purified phytohemagglutinin (PHA, The Wellcome Research Laboratories, Beckenham, England), pokeweed mitogen (PWM, Grand Island Biological Co., Grand Island,
N. Y.), streptokinase-streptodornase (SK/SD, Lederle Laboratories, Pearl River, N. Y.).

Gold compounds. The following compounds were utilized: gold sodium thiomalate (GST, Merck Chemical Div., Merck, Sharp \& Dohme \& Co., Inc., Rahway, N. J.), Gold trichloride $\left(\mathrm{AuCl}_{3} \cdot \mathrm{HCl} \cdot 3 \mathrm{H}_{2} \mathrm{O}\right.$, J. T. Baker Chemical Co., Phillipsburg, N. J.), and $d$, $l$-thiomalic acid (TMA, Merck, Sharp \& Dohme \& Co., Inc.).

Miscellaneous reagents. The following reagents were used where indicated: 2-mercaptoethanol (2-ME, EastmanKodak Co., Rochester, N. Y.) and $\alpha$-methyl-D-mannoside and mitomycin-C (Sigma Chemical Co., St. Louis, Mo.).

Culture medium. Cultures were carried out in medium RPMI-1640 (Microbiological Associates, Bethesda, Md.) supplemented with $0.3 \mathrm{mg} / \mathrm{ml}$ fresh $l$-glutamine, $10 \mu \mathrm{g} / \mathrm{ml}$ gentamicin, and $200 \mathrm{U} / \mathrm{ml}$ penicillin-G. The medium was further supplemented with either $10 \%$ fetal bovine serum (FBS, Microbiological Associates) or $10 \%$ heat-inactivated, pooled human $\mathrm{AB}$ serum.

Separation of PBM into adherent and nonadherent populations. In certain experiments, $\mathrm{PBM}$ were separated into adherent and nonadherent populations. This was accomplished by suspending PBM $\left(5 \times 10^{6} / \mathrm{ml}\right)$ in medium RPMI supplemented with $10 \%$ FBS and incubating them in $100 \times 20-\mathrm{mm}$ glass Petri dishes for $60 \mathrm{~min}$ at $37^{\circ} \mathrm{C}$. After this incubation, the nonadherent cells were removed by washing with warm medium and then pooled. The cells adherent to the glass Petri dish were then reincubated in medium containing $10 \%$ FBS for $30 \mathrm{~min}$ at $37^{\circ} \mathrm{C}$ after which they were vigorously washed with four changes of warm medium to remove loosely adherent cells. The adherent cells remaining after these washings were then bathed in phosphate-buffered saline ( $\mathrm{pH} 7.2$ ), chilled to $4^{\circ} \mathrm{C}$, and dislodged from the Petri dish with a rubber policeman. After washing, the cells were suspended in medium, exposed to $40 \mu \mathrm{g} / \mathrm{ml}$ mitomycin-C for $60 \mathrm{~min}$ at $37^{\circ} \mathrm{C}$, and washed four times. More than $90 \%$ of the resulting cell population was monocyte/macrophages as judged either morphologically with Euchrysine staining (24) or by determination of phagocytic cells using polystyrene latex particles. Viability was greater than $95 \%$ as estimated by trypan blue exclusion.

The nonadherent cells removed from the Petri dish on the first wash were pooled and further depleted of adherent cells by passage over nylon-wool (Fenwal Laboratories, Inc., Morton Grove, Ill.) columns, as previously described (20). The resultant population contained about $85-90 \%$ T lymphocytes as judged by rosette formation with sheep erythrocytes (25), and $0.1-0.8 \%$ monocytes as detected either morphologically with Euchrysine staining or by determination of phagocytically active cells.

Technique of cell culture and assay of lymphocyte DNA synthesis. Cultures were carried out in sterile microtiter plates with round-bottomed wells (Cooke Engineering Co., Alexandria, Va.). In some experiments, as noted in the text, cells were cultured in sterile microtiter plates with flatbottomed wells (Falcon Plastics, Division of BioQuest, Oxnard, Calif.). Routine cultures were done in triplicate, with each well containing $1 \times 10^{5}$ responding cells in $0.2 \mathrm{ml}$ of culture medium. In some experiments, the number of cells cultured per well was varied; in others, the responding cells were supplemented with mitomycin-C-treated monocyte/macrophages. The stimulating agent or an equal volume of medium as control was added directly to the cultures at the indicated final concentrations. Two-way mixed leukocyte reactions (MLR) were set up by mixing $5 \times 10^{4} \mathrm{PBM}$ from one individual with $5 \times 10^{4} \mathrm{PBM}$ from another unrelated individual in triplicate $0.2-\mathrm{ml}$ cultures. Mitogen-stimulated 
TABLE I

GST Inhibition of Human PBM Proliferation

\begin{tabular}{ccccc}
\hline \multirow{2}{*}{$\begin{array}{c}G S T \ddagger \\
\text { concn. } \\
\mu g / m l\end{array}$} & $\begin{array}{c}\text { PHA } \\
(n=15)\end{array}$ & $\begin{array}{c}\text { Con A } \\
(n=19)\end{array}$ & $\begin{array}{c}\text { SK/SD } \\
(n=4)\end{array}$ & $\begin{array}{c}\text { MLR } \\
(n=4)\end{array}$ \\
\cline { 2 - 5 }$\Delta c p m \S$ & & & & \\
0 & $85,105 \pm 6,013$ & $56,648 \pm 3,857$ & $26,844 \pm 2,953$ & $29,685 \pm 9,298$ \\
& & & & \\
$\%$ Inhibition" & & $5.6 \pm 2.7$ & $13.7 \pm 5.3$ & $0.8 \pm 2.9$ \\
1 & $4.3 \pm 2.8$ & $20.0 \pm 2.2$ & $27.0 \pm 4.3$ & $21.1 \pm 4.8$ \\
10 & $15.9 \pm 1.5$ & $23.8 \pm 1.9$ & $42.5 \pm 6.0$ & $47.6 \pm 11.7$ \\
25 & $21.5 \pm 1.9$ & $34.4 \pm 2.6$ & $75.2 \pm 3.8$ & $89.7 \pm 3.8$ \\
50 & $26.1 \pm 1.7$ & $61.3 \pm 2.9$ & $96.9 \pm 2.9$ & $99.4 \pm 0.4$ \\
100 & $35.6 \pm 3.9$ & & & \\
\hline
\end{tabular}

* $\left[{ }^{3} \mathrm{H}\right]$ Thymidine incorporation observed in cultures containing $1 \times 10^{5}$ responding cells per round-bottomed well using previously determined optimal concentrations of stimuli (PHA = $0.5 \mu \mathrm{g} / \mathrm{ml}$, Con A $=5.0 \mu \mathrm{g} / \mathrm{ml}$, SK/SD $=50 \mu \mathrm{g} / \mathrm{ml}$ ). Mitogen-stimulated cultures were incubated for 3 days, antigen-stimulated cultures for 5 days, and MLR cultures for 7 days. Data are expressed as mean $\pm S E M$ from $n$ separate experiments.

‡ Refers to concentration of GST of which gold constituted $50.5 \%$.

$\S$ Background $\left[{ }^{3} \mathrm{H}\right]$ thymidine incorporation of unstimulated cultures from 19 separate experiments, $\Delta \mathrm{cpm}=1,252 \pm 180$. Background $\Delta \mathrm{cpm}$ in cultures containing GST: $1 \mu \mathrm{g} / \mathrm{ml}, 1,343 \pm 249 ; 10 \mu \mathrm{g} / \mathrm{ml}, 1,320 \pm 224 ; 25 \mu \mathrm{g} / \mathrm{ml}, 1,248 \pm 259 ; 50 \mu \mathrm{g} / \mathrm{ml}$, $1,192 \pm 254 ; 100 \mu \mathrm{g} / \mathrm{ml}, 809 \pm 169$.

"Inhibition by $1 \mu \mathrm{g} / \mathrm{ml}$ GST not significant. Each response is significantly inhibited by all other concentrations of GST $(10-100 \mu \mathrm{g} / \mathrm{ml})$. Inhibition is significant at $P<0.001$ (paired sample $t$ test) for each situation except for inhibition of SK/SD response by $10 \mu \mathrm{g} / \mathrm{ml} \mathrm{GST}(P<0.05)$ and $25 \mu \mathrm{g} / \mathrm{ml}(P<0.01)$, and inhibition of MLR by 10 and $25 \mu \mathrm{g} / \mathrm{ml} \mathrm{GST}(P<0.02)$.

cultures were carried out in medium supplemented with $10 \%$ FBS whereas antigen-stimulated and MLR cultures were supplemented with $10 \%$ human serum. Cultures were incubated ( $72 \mathrm{~h}$ for mitogen stimulation, $120 \mathrm{~h}$ for antigen stimulation, and $168 \mathrm{~h}$ for MLR) at $37^{\circ} \mathrm{C}$ in a humidified atmosphere of $5 \% \mathrm{CO}_{2}$ and $95 \%$ air. $18 \mathrm{~h}$ before harvesting, $1 \mu \mathrm{Ci}$ of tritiated thymidine $(6.7 \mathrm{Ci} / \mathrm{mM}$, New England Nuclear, Boston, Mass.) was added to each well. Cells were harvested onto glass fiber filter paper using a semiautomated microharvesting device. Tritiated thymidine incorporation was then determined by liquid scintillation spectroscopy. All data are expressed as the difference in counts per minute between the means of triplicate stimulated and control cultures $(\Delta \mathrm{cpm})$. In some experiments, data are expressed as percent inhibition compared to control stimulation calculated according to the following formula: \% inhibition $=\left(1-\left[\Delta \mathrm{cpm}_{\mathrm{i}} / \Delta \mathrm{cpm}_{\mathrm{c}}\right]\right) \times 100$, where $\Delta \mathrm{cpm}_{\mathrm{i}}=$ proliferative response in the presence of a putative inhibitor and $\Delta \mathrm{cpm}_{\mathrm{c}}=$ proliferative response in control cultures.

\section{RESULTS}

GST inhibition of human lymphocyte proliferation. GST inhibited the proliferative responses of normal human lymphocytes induced by either of the mitogens PHA or Con A, the antigen SK/SD or allogenic lymphocytes in a MLR as depicted in Table I. The degree of suppression observed was dependent on the concentration of GST, with significant inhibition seen with $10 \mu \mathrm{g} / \mathrm{ml}$. The data shown in Table I were obtained using concentrations of mitogens or antigens which gave maximum responses in control cultures containing no gold. When suboptimal concentrations of mitogen were employed, the degree of GST inhibition of lymphocyte proliferation was markedly greater than that observed in cultures stimulated with concentrations yielding maximal $\left[{ }^{3} \mathrm{H}\right]$ thymidine incorporation (Table II). Moreover, the concentration or nature of the serum used to support the cultures appeared to have little effect on GST inhibition. Thus, varying the concentration of FBS from 5 to $20 \%$ had no significant effect on GST inhibition of the PHA response. Furthermore, GST suppression of PHA responsiveness was similar in cultures supported by either human serum or FBS (data not shown).

Experiments were carried out to determine whether GST caused an actual depression in the degree of mitogen-induced lymphocyte proliferation or merely altered the kinetics of these responses (Fig. 1). In these studies, PBM were cultured for 2-6 days with 
TABLE II

GST Inhibition of Optimal and Suboptimal Mitogenic Stimulation

\begin{tabular}{|c|c|c|c|c|}
\hline \multirow{3}{*}{$\begin{array}{c}\text { GST } 1 \\
\text { concn. } \\
\mu \mathrm{g} / \mathrm{ml}\end{array}$} & \multicolumn{4}{|c|}{ Lymphocyte DNA synthesis* } \\
\hline & \multicolumn{2}{|c|}{$\operatorname{Con} \mathrm{A}$} & \multicolumn{2}{|c|}{ PHA } \\
\hline & $1 \mu \mathrm{g} / \mathrm{ml}$ & $5 \mu \mathrm{g} / \mathrm{ml}$ & $0.1 \mu \mathrm{g} / \mathrm{ml}$ & $0.5 \mu \mathrm{g} / \mathrm{ml}$ \\
\hline \multicolumn{5}{|l|}{$\Delta c p m$} \\
\hline 0 & 15,315 & 49,800 & 51,198 & 63,220 \\
\hline \multicolumn{5}{|c|}{$\%$ Inhibition } \\
\hline 10 & 48.9 & 19.5 & 28.4 & 13.9 \\
\hline 25 & 68.8 & 42.1 & 50.5 & 34.8 \\
\hline
\end{tabular}

* $\left[{ }^{3} \mathrm{H}\right]$ Thymidine incorporation observed in cultures containing $1 \times 10^{5}$ responding cells per round-bottomed well. Each term represents the mean of triplicate determinations.

PHA, Con A, or medium control in the presence or absence of $10 \mu \mathrm{g} / \mathrm{ml} \mathrm{GST}$, and $\left[{ }^{3} \mathrm{H}\right]$ thymidine incorporation was assayed daily. Lymphocyte DNA synthesis induced by PHA and Con A in the absence of GST is shown in Fig. 1 (insert) as a function of the length of culture. Peak response to both mitogens is seen after a 3-day incubation. GST-mediated suppression of each of these responses was observed throughout the period of observation. There was no tendency for the degree of lymphocyte proliferation in GST-inhibited cultures to approach that manifested by control cultures. On the contrary, as incubation was prolonged beyond 3 days, the degree of GST-mediated inhibition became more marked, suggesting the possibility that prolonged incubation in GST may have an adverse effect on lymphocyte responsiveness. This point will be addressed in more detail in a subsequent section. For the remaining experiments, a standard 3-day incubation was employed to analyze the effect of GST on mitogen stimulation.

To determine whether suppression of lymphocyte proliferation required the intact gold thio molecule or merely the sulfur-containing ligand, the inhibitory effect of GST was compared to that of thiomalic acid (TMA). Fig. 2 depicts the percent inhibition of the Con $\mathrm{A}$ response as a function of the molar concentration of each of these reagents. TMA caused no significant inhibition of the Con A response and GST produced significant suppression at concentrations as low as $26 \mu \mathrm{M}(10 \mu \mathrm{g} / \mathrm{ml})$.

The effect of gold chloride $\left(\mathrm{AuCl}_{3} \cdot \mathrm{HCl} \cdot 3 \mathrm{H}_{2} \mathrm{O}\right)$ on Con A responsiveness was next examined to ascertain whether the inhibitory capacity of gold compounds was limited to those in which gold was complexed to a sulfur-containing ligand (Table III). The ability of gold chloride to inhibit Con A-induced lymphocyte proliferation was similar to that manifested by GST at a low concentration $(10 \mu \mathrm{g} / \mathrm{ml})$ but exceeded the inhibitory capacity of GST at higher concentrations $(25,50 \mu \mathrm{g} / \mathrm{ml})$. These data suggest that inhibition of lymphocyte proliferation induced by gold compounds is mediated by the gold moiety itself and is not dependent on the ligand.

Effect of immediate and delayed addition of GST on lymphocyte proliferation induced by Con A. Lymphocyte DNA synthesis assayed by $\left[{ }^{3} \mathrm{H}\right]$ thymidine incorporation is a relatively late occurrence in a complex series of biological events triggered by mitogens $(26,27)$. To determine whether there was a particular step in this sequence of events which was sensitive to inhibition by gold, GST was added to control and Con A-stimulated cultures either at the initiation of the incubation or at varying times thereafter (Fig. 3). The total length of incubation was $72 \mathrm{~h}$ for each experimental point. The stippled area indicates the Con A response of these cells (mean $\Delta c p m \pm S E M$ ) when incubated for $72 \mathrm{~h}$ with no added gold. When GST was added to the cultures at their inception, concen-

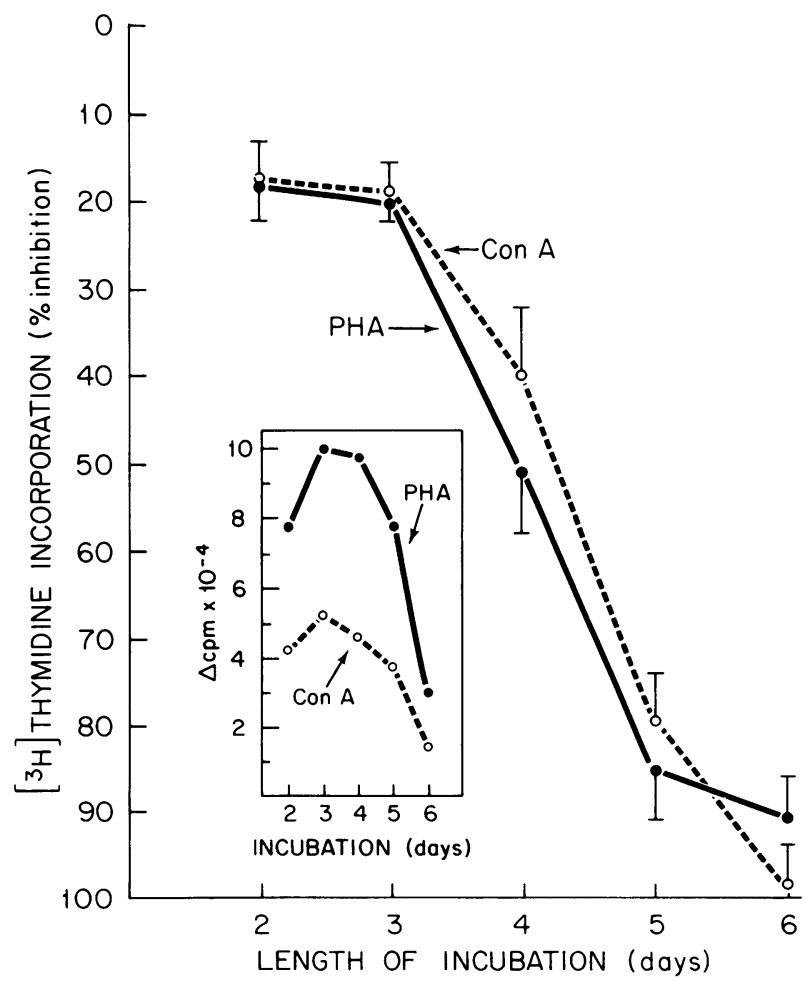

FIGURE 1 GST-mediated inhibition of the response of PBM to Con A and PHA as a function of the length of incubation. PBM $\left(1 \times 10^{5} /\right.$ well $)$ were incubated with $5 \mu \mathrm{g} / \mathrm{ml}$ Con A, 0.5 $\mu \mathrm{g} / \mathrm{ml}$ PHA, or an equal volume of medium as control for $2-6$ days at $37^{\circ} \mathrm{C}$ in the presence or absence of $10 \mu \mathrm{g} / \mathrm{ml}$ GST and assayed for $\left[{ }^{3} \mathrm{H}\right]$ thymidine incorporation. Insert depicts proliferative response $(\Delta \mathrm{cpm})$ of control cells cultured without gold. Each point represents the mean $\pm \mathrm{SEM}$ of three separate experiments. 


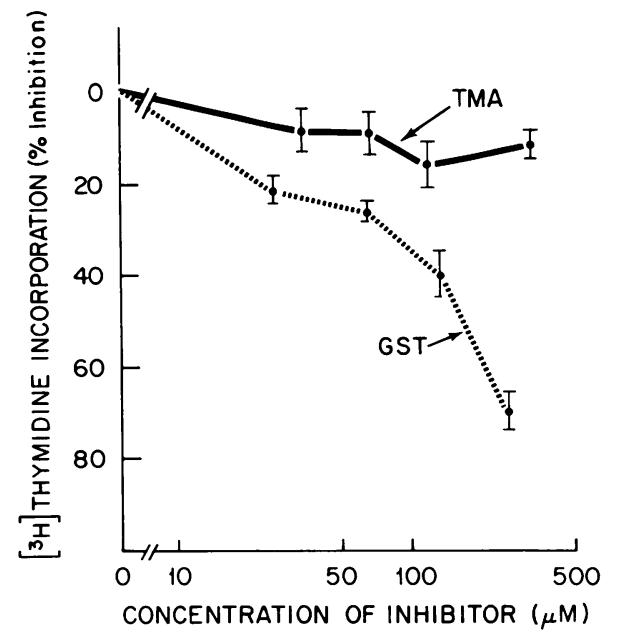

FIGURE 2 Comparison of the effect of GST and TMA on Con A-induced proliferative responses of PBM. Each point represents the mean $\pm S E M$ of four separate experiments.

tration-dependent inhibition of the Con A response was observed with $25 \mu \mathrm{g} / \mathrm{ml}$ resulting in a $30.8 \%$ inhibition, and $100 \mu \mathrm{g} / \mathrm{ml}$ suppressing the response by $68.5 \%$. When the addition of GST was delayed by progressively longer intervals from the beginning of the culture, as indicated on the abscissa, the degree of resultant inhibition became progressively less marked. There was no effect on proliferation when GST was present only for the terminal $24 \mathrm{~h}$ of culture. These findings indicate that GST inhibition does not result merely from a nonspecific blocking of either thymidine uptake or DNA synthesis by lymphocytes. Moreover, the observation that inhibition by gold was most effective when GST was present from the initiation of culture suggests that gold acts by blocking an early step in the sequence of events resulting in lymphocyte DNA synthesis. Similar results were observed when PHA was used as the stimulus or when gold chloride was used as the inhibitor (data not shown).

Inability of GST to inhibit DNA synthesis by Con A-activated lymphocytes. The previous experiments suggested that the major effect of gold was to inhibit an early step in the sequence of mitogentriggered events resulting in lymphocyte DNA synthesis. To investigate this possibility further, the effect of GST on the degree of lymphocyte proliferation, manifested by a population of PBM previously activated by Con $\mathrm{A}$ in the absence of gold, was investigated (Table IV). PBM were incubated with 5 $\mu \mathrm{g} / \mathrm{ml}$ Con $\mathrm{A}$ or an equal volume of medium as control for $24 \mathrm{~h}$ at $37^{\circ} \mathrm{C}$. At the end of this period of activation, the cells were incubated twice with $40 \mathrm{mM}$ $\alpha$-methyl-D-mannoside for $10 \mathrm{~min}$ at room temperature and washed to remove excess Con A (28). The cells
TABLE III

Gold Inhibition of Con A-Induced Lymphocyte Proliferation: Comparison of GST and Gold Chloride

\begin{tabular}{ccc}
\hline \multirow{2}{*}{$\begin{array}{c}\text { Concentration } \\
\text { of inhibitor }\end{array}$} & \multicolumn{3}{c}{$\left[{ }^{3} \mathrm{H}\right]$ Thymidine incorporation } \\
\cline { 2 - 3 } & \multicolumn{3}{c}{ GST } & Gold chloribition $\S$ \\
\hline$\mu g / m l$ & $17.0 \pm 3.2$ & $14.5 \pm 4.5$ \\
10 & $24.8 \pm 4.7$ & $52.0 \pm 8.3$ \\
25 & $42.3 \pm 6.6$ & $91.4 \pm 3.3$ \\
50 & & \\
\hline
\end{tabular}

* GST; gold content: $50.5 \%$.

\$ Gold Trichloride $\left(\mathrm{AuCl}_{3} \cdot \mathrm{HCl} \cdot 3 \mathrm{H}_{2} \mathrm{O}\right)$; gold content: $49.2 \%$. $\$$ Each term represents the mean \pm SEM of five separate experiments.

then were suspended in fresh medium, supplemented with $10 \%$ FBS, and aliquoted into the wells of microtiter plates $\left(1 \times 10^{5} /\right.$ well $)$. If the cells were assayed for $\left[{ }^{3} \mathrm{H}\right]$ thymidine incorporation at this point, no significant difference was noted between Con Aactivated and control cells (data not shown). However, when the cells were incubated at $37^{\circ} \mathrm{C}$ for $48 \mathrm{~h}$ after the period of mitogen exposure, significant $\left[{ }^{3} \mathrm{H}\right]$ thymidine incorporation developed in the Con A-activated population $(\triangle \mathrm{CPM}=22,179 \pm 1,545)$. As

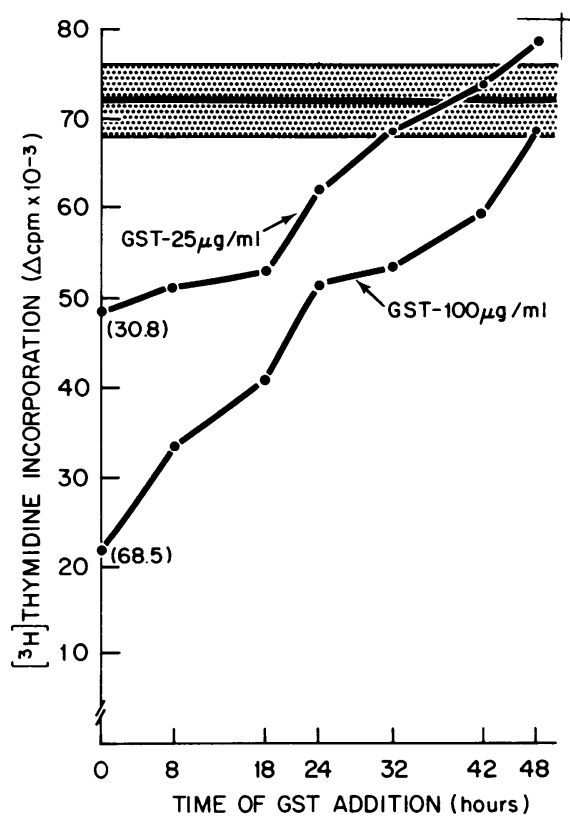

FIGURE 3 Effect of delayed addition of GST on Con Ainduced lymphocyte DNA synthesis. PBM were cultured for $72 \mathrm{~h}$ with or without $5 \mu \mathrm{g} / \mathrm{ml}$ Con $\mathrm{A}$. The proliferative response of these cells cultured without GST is indicated by the stippled area $(\Delta \mathrm{cpm}=71,924 \pm 4,036) .25$ or $100 \mu \mathrm{g} / \mathrm{ml}$ GST was added either at the initiation of culture or at varying times thereafter. Each point represents the mean of triplicate determinations. 
TABLE IV

Failure of GST to Inhibit DNA Synthesis of Lymphocytes Previously Activated by Con A

\begin{tabular}{ccc}
\hline \multirow{2}{*}{$\begin{array}{c}\text { GST concn. during } \\
\text { last } 48 \mathrm{~h} \text { of } \\
\text { incubation }\end{array}$} & \multicolumn{2}{c}{$\begin{array}{c}\text { DNA synthesis by Con A-activated PBM* } \\
\text { cultured with: }\end{array}$} \\
\cline { 2 - 3 } & Medium & Con A \\
\hline$\mu g / m l$ & ${ }^{3} H$ Thymidine & incorporation- $\Delta c p m \ddagger$ \\
0 & $22,179 \pm 1,545$ & $95,995 \pm 2,589$ \\
10 & $20,952 \pm 1,421$ & $82,626 \pm 3,058$ \\
25 & $22,162 \pm 2,643$ & $76,637 \pm 2,988$ \\
50 & $21,155 \pm 2,523$ & $65,525 \pm 1,352$ \\
\hline
\end{tabular}

* PBM were incubated in test tubes $\left(1 \times 10^{6} / \mathrm{ml}\right.$ in medium containing $10 \%$ FBS) with $5 \mu \mathrm{g} / \mathrm{ml}$ Con A or an equal volume of medium as control for $24 \mathrm{~h}$ at $37^{\circ} \mathrm{C}$. At the end of this incubation, the cells were washed with $40 \mathrm{mM} \alpha$-methyl-Dmannoside, suspended in fresh medium containing $10 \%$ FBS, and aliquoted into the wells of microtiter plates $\left(1 \times 10^{5} / \mathrm{well}\right)$. After an additional 48 -h incubation at $37^{\circ} \mathrm{C}$ with GST at the indicated final concentration, $\left[{ }^{3} \mathrm{H}\right]$ thymidine incorporation was assayed. During the final $48 \mathrm{~h}$, cultures were supplemented with either $5 \mu \mathrm{g} / \mathrm{ml}$ Con A or an equal volume of medium. $\Delta \mathrm{cpm}$ indicates the difference in $\left[{ }^{3} \mathrm{H}\right]$ thymidine incorporation between Con A-activated and control PBM. Mean $\left[{ }^{3} \mathrm{H}\right]$ thymidine incorporation of control PBM was $1,121 \mathrm{cpm}$. This was not significantly affected by presence of GST during the final $48 \mathrm{~h}$ of incubation.

$\$$ Each term represents the mean \pm SEM of four separate experiments.

shown in Table IV, when varying concentrations of GST were present in cultures of Con A-activated or control lymphocytes during this latter 48-h incubation, no significant inhibition of DNA synthesis was observed. If an additional $5-\mu \mathrm{g} / \mathrm{ml}$ Con A was added to the Con A-activated cells during the last $48 \mathrm{~h}$ of incubation, a marked increase in the degree of $\left[{ }^{3} \mathrm{H}\right]$ thymidine incorporation was observed $(\Delta \mathrm{cpm}$ $=95,995 \pm 2,589)$. This may have resulted from the induction of a response in cells which had not been activated initially or perhaps by inducing daughter cells of the original Con A-activated population to divide again. In either event, GST caused concentration-dependent inhibition of $\left[{ }^{3} \mathrm{H}\right]$ thymidine incorporation induced by the addition of Con A to these cultures without affecting DNA synthesis resulting from the initial Con $\mathrm{A}$ activation. These data indicate that GST inhibition of lymphocyte proliferation does not result from nonspecific toxicity or interference with the assay system employed. Moreover, the observation that the addition of GST after $24 \mathrm{~h}$ of mitogen activation does not alter subsequent lymphocyte DNA synthesis supports the concept that gold exerts its major influence during the initial induction phase of lymphocyte activation before DNA synthesis actually begins.
Reversibility of GST inhibition of lymphocyte proliferation. $\quad$ PBM were incubated with $5 \mu \mathrm{g} / \mathrm{ml}$ Con A or an equal volume of medium as control for $24 \mathrm{~h}$ at $37^{\circ} \mathrm{C}$ in the presence or absence of various concentrations of GST. At the end of this period, the cells were washed with $\alpha$-methyl-D-mannoside as previously described and then washed four times with medium to remove both excess Con A and GST. The cells then were suspended in fresh medium containing $10 \%$ FBS, aliquoted into the wells of microtiter plates $\left(1 \times 10^{5} /\right.$ well $)$, incubated for an additional $48 \mathrm{~h}$ at $37^{\circ} \mathrm{C}$, and assayed for incorporation of $\left[{ }^{3} \mathrm{H}\right]-$ thymidine. As seen in Table V, the presence of GST during the period of activation resulted in no diminution in subsequent $\left[{ }^{3} \mathrm{H}\right]$ thymidine incorporation if the inhibitor was removed after the first $24 \mathrm{~h}$. These observations suggest that the inhibitory effect of GST did not result merely from an alteration in the uptake or handling of functionally relevant mitogen by PBM.

The inverse relationship between monocyte number and GST inhibition of lymphocyte proliferation. Two sets of observations suggested the possibility that the effect of GST on mitogen and antigen responsiveness might result from interference with monocyte or macrophage function. First, the initiation of antigen- and mitogen-induced T-lymphocyte DNA synthesis requires the active participation of an ac-

\section{TABLE $\mathrm{V}$}

GST Inhibition of Con A Responsiveness: Lack of Effect when Present only during the Initial $24 \mathrm{H}$

\begin{tabular}{cc}
\hline $\begin{array}{c}\text { GST concn.* during } \\
\text { Con A activation }\end{array}$ & $\begin{array}{c}{\left[{ }^{3} \mathrm{H}\right] \text { Thymidine incorporationt }} \\
\text { by Con A-activated PBM }\end{array}$ \\
\hline$\mu g / m l$ & $\Delta c p m$ \\
0 & $23,233 \pm 2,824$ \\
25 & $20,828 \pm 1,797$ \\
100 & $21,881 \pm 7,829$
\end{tabular}

* PBM were incubated in test tubes $\left(1 \times 10^{6} / \mathrm{ml}\right.$ in medium containing $10 \%$ FBS) with $5 \mu \mathrm{g} / \mathrm{ml}$ Con A or an equal volume of medium as control and GST at the indicated final concentration. After $24 \mathrm{~h}$ incubation at $37^{\circ} \mathrm{C}$, the cells were exposed to $40 \mathrm{mM} \alpha$-methyl-D-mannoside, washed four times, suspended in fresh medium containing $10 \%$ FBS, and aliquoted into the wells of microtiter plates $\left(1 \times 10^{5} /\right.$ well $)$. After an additional $48 \mathrm{~h}$ incubation at $37^{\circ} \mathrm{C}$ without GST or additional mitogen, $\left[{ }^{3} \mathrm{H}\right]$ thymidine incorporation was assayed. $\Delta \mathrm{cpm}$ indicates the difference in $\left[{ }^{3} \mathrm{H}\right]$ thymidine incorporation between Con A-activated and control PBM. Mean $\left[{ }^{3} \mathrm{H}\right]$ thymidine incorporation of control PBM was $980 \mathrm{cpm}$. This was not significantly affected by presence of GST during the initial $24 \mathrm{~h}$ of incubation.

$\$$ Each term represents the mean \pm SEM of three separate experiments. When GST was present during the entire $72 \mathrm{~h}$ incubation, $25 \mu \mathrm{g} / \mathrm{ml}$ led to $25.8 \pm 5.4 \%$ inhibition and 100 $\mu \mathrm{g} / \mathrm{ml}$ led to $65.1 \pm 3.9 \%$ inhibition of Con A responsiveness. 
cessory cell (17-22). In populations of human PBM, the monocyte subserves this function $(18,21,22)$. Second, GST has been demonstrated to be actively internalized by macrophages in vivo (29-31) and to inhibit certain enzyme systems (32), as well as functional capabilities of these cells (33). Thus, the action of gold on mitogen- and antigen-induced lymphocyte proliferation might not result from inhibition of lymphocyte responsiveness per se, but rather from interference with the requisite function of the monocyte population in the initiation or support of such responses.

The magnitude of the proliferative response of $\mathrm{T}$ lymphocytes induced by mitogens is dependent on the number of accessory cells supporting that response $(15,20,22)$. This accessory cell requirement is most easily observed in cultures of $\mathrm{T}$ lymphocytes which have been partially depleted of adherent cells. In such cultures, the degree of mitogen-induced lymphocyte $\left[{ }^{3} \mathrm{H}\right]$ thymidine incorporation varies directly with the number of accessory cells added. We reasoned, therefore, that if gold inhibited lymphocyte proliferation by causing a partial interference with a requisite monocyte function, this inhibitory effect would be accentuated in cultures in which the number of monocytes was decreased. Conversely, a GST-induced monocyte dysfunction might be overcome by supplementation of the cultures with excess monocytes. Fig. 4 depicts the relationship between the number of monocytes supporting a mitogen-induced proliferative response and the degree of GST inhibition of that response. GST inhibition of the Con A response observed in a standard population of PBM is shown. This population of PBM contained between 25 and $30 \%$ monocytes. When the PBM were depleted of adherent cells by sequential Petri dish plating and nylon column passage, the resultant population contained $0.5 \%$ monocytes. Two differences were observed in the Con A response of the monocyte-depleted peripheral blood lymphocytes (PBL) compared to PBM. First, the magnitude of the response in terms of $\Delta \mathrm{cpm}$ (A) was diminished (from 72,606 to 18,396) and second, the degree of inhibition produced by all concentrations of GST was markedly greater (B). When the PBL were supplemented with purified autologous mitomycin-C-treated monocytes to levels equivalent to that found in unfractionated PBM $\left(2.5 \times 10^{4}\right.$ monocytes/ $1 \times 10^{5} \mathrm{PBL}$ ), the magnitude of the Con A response was restored to that observed with PBM. Likewise, the degree of GST inhibition was decreased and seen to approximate that observed with PBM. When twice as many monocytes were added to the cultures, GSTmediated inhibition of the Con A response was further decreased, although there was no further change in the magnitude of $\left[{ }^{3} \mathrm{H}\right]$ thymidine incorporation observed in cultures without added GST. The

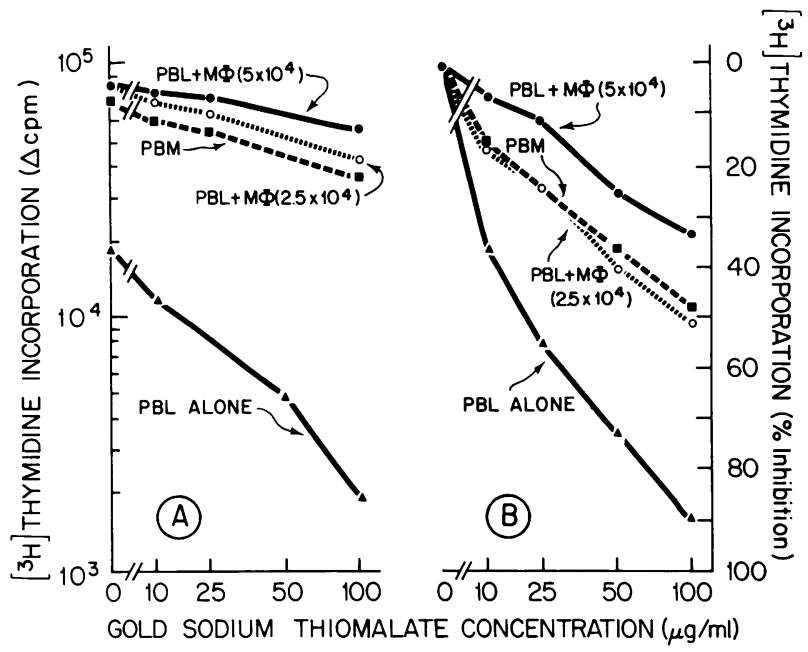

FIgURE 4 Con A-induced $\left[{ }^{3} \mathrm{H}\right]$ thymidine incorporation as a function of GST concentration. PBM or PBL $\left(1 \times 10^{5} /\right.$ well $)$ were cultured in flat-bottomed microtiter wells with or without $5 \mu \mathrm{g} / \mathrm{ml}$ Con A. PBL were cultured either alone or supplemented with mitomycin-C-treated monocytes (2.5 $\times 10^{4}$ or $5 \times 10^{4} /$ well). Cultures also contained GST at final concentration indicated on the abscissa. After $72 \mathrm{~h}$ incubation, $\left[{ }^{3} \mathrm{H}\right]$ thymidine incorporation was determined and expressed as $\Delta \mathrm{cpm}(\mathrm{A})$ and percent inhibition of control stimulation (B). Each point represents the mean of triplicate determinations. When cultured alone, the mitomycin-C-treated monocyte population manifested no significant degree of Con Ainduced $\left[{ }^{3} \mathrm{H}\right]$ thymidine incorporation.

inverse relationship between monocyte number and the degree of GST inhibition of lymphocyte proliferation supports the contention that gold acts not by inhibiting the potential responsiveness of the lymphocytes per se, but rather by interfering with a critical function subserved by monocytes in these responses.

Effect of prolonged GST preincubation on subsequent lymphocyte proliferation. Since previous observations (Fig. 1) had suggested that decreased lymphocyte proliferation might result from lengthy GST exposure, experiments were undertaken to determine whether preincubating PBM with GST would alter their mitogen responsiveness. $\mathrm{PBM}$ were incubated with GST for various lengths of time at $37^{\circ} \mathrm{C}$. The cells were then washed extensively, aliquoted into the wells of microtiter plates, and incubated, with or without mitogen, for $72 \mathrm{~h}$ at $37^{\circ} \mathrm{C}$ in fresh medium containing no gold. These latter cultures were carried out at a variety of cell densities (1.25 $\times 10^{4}-1.0 \times 10^{5} /$ well $)$ in microtiter plates with flatbottomed wells. This modified limiting dilution culture technique has been described previously (20) as a way to accentuate small differences in accessory cell number or function which might be missed in standard higher density cultures.

PBM were cultured with varying concentrations of 


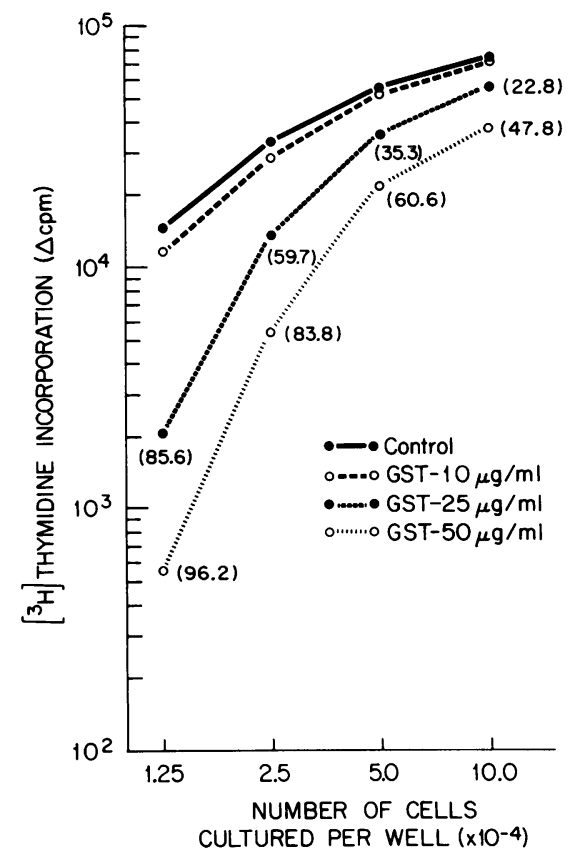

Figure 5 Effect of $72 \mathrm{~h}$ GST preincubation on subsequent Con A-induced lymphocyte proliferation. PBM were incubated with GST at the indicated concentration for $72 \mathrm{~h}$ as previously described. The cells were then washed, aliquoted into flat-bottomed microtiter wells at various cell densities, incubated for $72 \mathrm{~h}$ with or without $5 \mu \mathrm{g} / \mathrm{ml} \mathrm{Con} \mathrm{A,} \mathrm{and} \mathrm{assayed}$ for $\left[{ }^{3} \mathrm{H}\right]$ thymidine incorporation. Each point represents the mean of triplicate determinations. Numbers in parentheses indicate percent inhibition compared to control.

GST for $72 \mathrm{~h}$. Such preincubation of PBM in 10 $\mu \mathrm{g} / \mathrm{ml}$ of GST had no significant effect on the ability of these cells to respond to Con A when subsequently cultured in the absence of the gold compound (Fig. 5). However, a 72-h preincubation with higher concentrations of GST (25 or $50 \mu \mathrm{g} / \mathrm{ml}$ ) rendered PBM deficient in their ability to respond to Con A. Differences in Con A responsiveness between these cells and control cells became markedly more pronounced when cultured at lower cell densities. These cells, likewise, were deficient in their responses to PHA, PWM, and SK/SD (data not shown). These findings could not be explained by GST-induced cell death since the absolute number of cells surviving control and GST-containing cultures was not significantly different and all cultures manifested similar viability as assessed by trypan blue exclusion after the $72 \mathrm{~h}$ incubation.

Development of GST-induced depression of mitogen responsiveness required prolonged incubation. Thus, culture of PBM for $24 \mathrm{~h}$ with varying concentrations of GST had no significant effect on the ability of these cells to respond to mitogens when subsequently cultured in the absence of gold (Table VI). Furthermore, limiting dilution analysis did not reveal subtle differences resulting from GST preincubation (data not shown).

The data obtained from limiting dilution analysis (Fig. 5), suggested that gold-induced monocyte dysfunction might explain the depressed responsiveness of PBM observed after prolonged GST exposure. For this reason, the potential ability of fresh monocytes to restore mitogen responsiveness to PBM which had been preincubated with GST was tested (Fig. 6). PBM were preincubated for 5 days in varying concentrations of GST. The cells were then extensively washed, aliquoted into the wells of microtiter plates, cultured for $72 \mathrm{~h}$ with or without Con $\mathrm{A}$, and assayed for $\left[{ }^{3} \mathrm{H}\right]$ thymidine incorporation. These latter cultures were supplemented with either fresh medium as control, 2-ME, or fresh autologous monocytes. Those cells which had been preincubated with 10 $\mu \mathrm{g} / \mathrm{ml}$ of GST exhibited responses to Con A on subsequent culture which were not dissimilar from control cells which had been preincubated in medium alone. However, cells which had been preincubated with higher concentrations of GST ( 25 or $50 \mu \mathrm{g} / \mathrm{ml}$ ) showed a marked depression in Con A responsiveness when recultured alone. Addition of $2-\mathrm{ME}$ to these cultures only partially restored responsiveness. However, supplementation of these cultures with fresh autologous monocytes resulted in a complete restoration of lymphocyte DNA synthesis to control levels. These data suggest that prolonged exposure to GST had resulted in monocyte dysfunction and not an alteration in potential lymphocyte responsiveness.

To confirm these observations, purified monocytes were incubated for $72 \mathrm{~h}$ at $37^{\circ} \mathrm{C}$ with 10 or $25 \mu \mathrm{g} / \mathrm{ml}$ GST or an equal volume of medium as control. The cells were then washed extensively and evaluated

TABLE VI

Effect of 24 H GST Preincubation on Subsequent Mitogen Responsiveness

\begin{tabular}{ccccc}
\hline \multirow{2}{*}{$\begin{array}{c}\text { GST concn. during } \\
24 \mathrm{~h} \text { preincubation }\end{array}$} & \multicolumn{5}{c}{ Lymphocyte DNA synthesis } \\
\cline { 2 - 5 } & 0 & PHA & Con A & PWM \\
\hline$\mu g / m l$ & \multicolumn{4}{c}{$\left[{ }^{3} H\right]$ Thymidine incorporation-cpm $\times 10^{-3} \ddagger$} \\
0 & $0.6 \pm 0.2$ & $82.2 \pm 1.5$ & $72.7 \pm 1.4$ & $21.9 \pm 0.3$ \\
10 & $0.6 \pm 0.1$ & $74.5 \pm 5.5$ & $68.4 \pm 1.1$ & $22.5 \pm 0.4$ \\
25 & $0.6 \pm 0.1$ & $85.1 \pm 1.4$ & $73.5 \pm 1.2$ & $22.1 \pm 0.8$ \\
50 & $0.5 \pm 0.1$ & $77.5 \pm 2.5$ & $65.6 \pm 2.6$ & $20.8 \pm 0.3$
\end{tabular}

* PBM were incubated in test tubes $\left(1 \times 10^{6} / \mathrm{ml}\right)$ with GST at various concentrations for $24 \mathrm{~h}$ at $37^{\circ} \mathrm{C}$. The cells were then washed four times to remove GST, suspended in fresh medium, and aliquoted into microtiter wells $\left(1 \times 10^{5} /\right.$ well $)$. The cells were then incubated with $0.5 \mu \mathrm{g} / \mathrm{ml}$ PHA, $5 \mu \mathrm{g} / \mathrm{ml}$ Con A, or PWM (1:100) or an equal volume of medium as control for $72 \mathrm{~h}$, and assayed for $\left[{ }^{3} \mathrm{H}\right]$ Thymidine incorporation. $\$$ Each term represents the mean \pm SEM of triplicate determinations. 


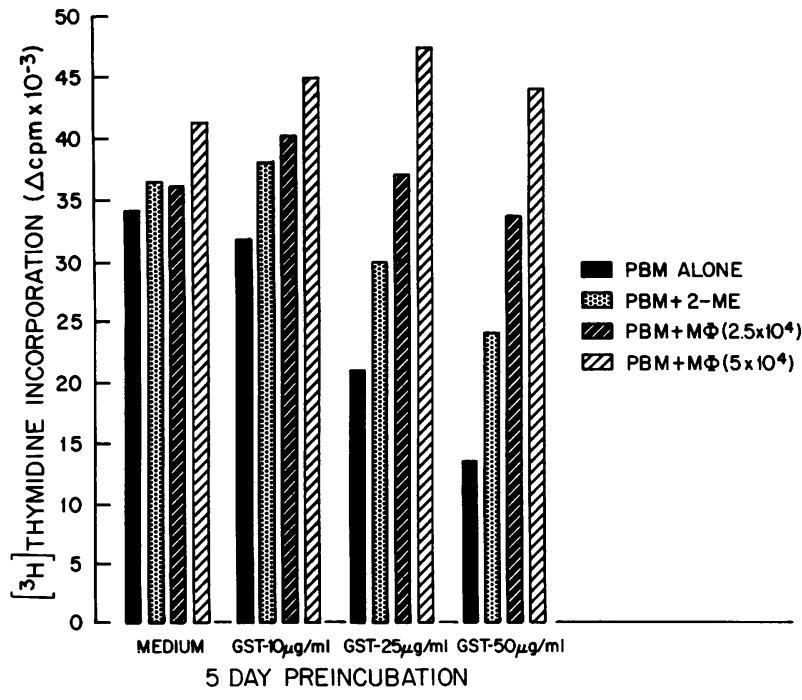

FIGURE 6 Monocyte rescue of GST-induced depression of Con A responsiveness. PBM were preincubated with various concentrations of GST for 5 days at $37^{\circ} \mathrm{C}$. The cells were then washed four times, suspended in fresh medium containing $10 \%$ FBS, aliquoted into flat-bottomed microtiter wells $\left(2.5 \times 10^{4} /\right.$ well $)$, incubated with or without $5 \mu \mathrm{g} / \mathrm{ml}$ Con A for $72 \mathrm{~h}$ at $37^{\circ} \mathrm{C}$, and assayed for $\left[{ }^{3} \mathrm{H}\right]$ thymidine incorporation. These latter cultures were supplemented with either medium as control, $25 \mu \mathrm{M} 2-\mathrm{ME}$ or fresh autologous monocytes (MФ). The monocytes had been treated with mitomycin-C and manifested no significant $\left[{ }^{3} \mathrm{H}\right]$ thymidine incorporation in response to Con A when cultured alone. Each bar represents the mean of triplicate determinations.

for their ability to support mitogen responsiveness in populations of fresh PBL which had been depleted of adherent cells (Fig. 7). When fresh adherent celldepleted PBL were cultured alone, no significant degree of DNA synthesis was triggered by Con A. Supplementation of these cultures with aged control monocyte or macrophage (M $\Phi)$ led to the development of a vigorous proliferative response to Con $\mathrm{A}$. By contrast, $M \Phi$, which had been preincubated for $72 \mathrm{~h}$ with GST, were markedly deficient in their ability to support Con A-induced T-lymphocyte proliferation. This deficiency could not be explained by cell death, since cell yields, both in terms of absolute number and viability as gauged by trypan blue exclusion, were similar in all three monocyte populations. Furthermore, it is unlikely that these observations resulted from carry over of GST or induction of a suppressor cell since GST-preincubated monocytes did not inhibit Con Ainduced DNA synthesis of PBL supported by control monocytes (data not shown).

\section{DISCUSSION}

A number of clinical trials have established that chrysotherapy can lead not only to amelioration of the symptoms of rheumatoid arthritis but also to actual remissions of disease activity (10-13). Since the patho- genesis of chronic rheumatoid synovitis is thought to involve immunologic mechanisms (1), it seems reasonable to suggest that the therapeutic efficacy of gold compounds may relate to their ability to modify immune responsiveness. Although a number of studies have indicated that gold compounds may inhibit nonspecific inflammatory responses in a variety of experimental models (33-35), evidence as to whether these agents exert a direct effect on lymphocyte responsiveness remains conflicting (36).

To conclude that the effects of gold compounds observed in vitro have significance in vivo, such effects should be observed with concentrations attainable in treated patients. A number of studies have quantitated the levels of gold present in various body fluids and tissues after therapy with different gold compounds. Although blood concentration of gold has been shown to depend on variables such as dosage schedule and excretion rate, serum levels attained in patients treated with gold tend to be in the range of $2-5 \mu \mathrm{g} / \mathrm{ml}(37-42)$, equivalent to $4-10 \mu \mathrm{g} / \mathrm{ml}$ of GST.

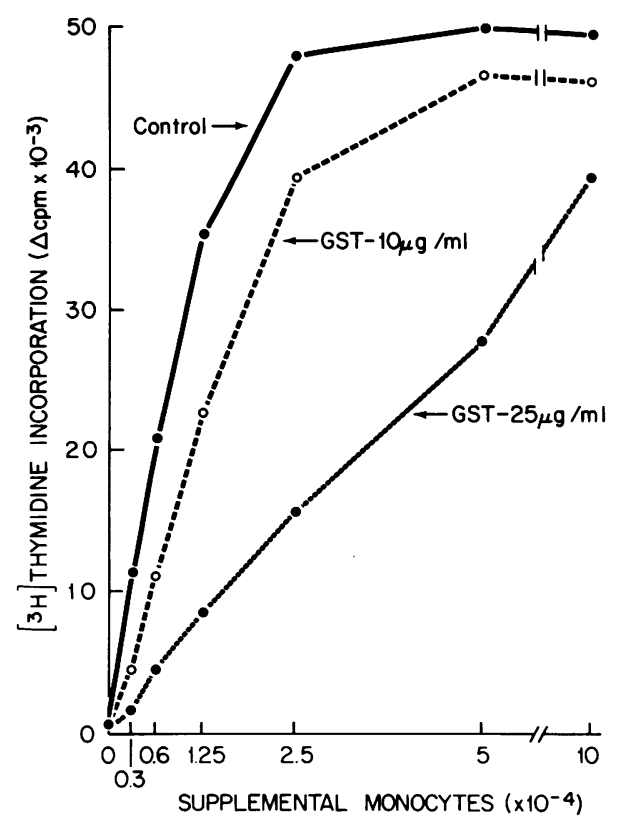

FIGURE 7 The effect of GST preincubation on the ability of monocytes to support Con A-induced proliferative responses. Purified monocytes were suspended in medium containing $10 \%$ FBS $\left(0.5 \times 10^{6} / \mathrm{ml}\right)$, and cultured in test tubes with or without GST. After a 72 -h incubation at $37^{\circ} \mathrm{C}$, the cells were washed three times, exposed to $40 \mu \mathrm{g} / \mathrm{ml}$ mitomycin-C for $60 \mathrm{~min}$ at $37^{\circ} \mathrm{C}$, and washed four more times. They were then mixed with fresh, autologous, adherent-cell depleted PBL $\left(2.5 \times 10^{4} /\right.$ well $)$ in flat-bottomed microtiter wells and incubated with $5 \mu \mathrm{g} / \mathrm{ml}$ Con $A$ or an equal volume of medium as control. After a 72 -h incubation at $37^{\circ} \mathrm{C},\left[{ }^{3} \mathrm{H}\right]$ thymidine incorporation was determined. Each point represents the mean of triplicate determinations. Con A-induced $\left[{ }^{3} \mathrm{H}\right]-$ thymidine incorporation manifested by PBL cultured alone resulted in $\Delta \mathrm{cpm}=248$. The monocytes, when cultured alone, made no significant response to Con $\mathrm{A}$. 
However, the concentration of gold in the blood does not appear to correlate with either the therapeutic or toxic effects of gold compounds in man (38-42), suggesting that the anti-inflammatory action of gold compounds is not related to serum gold level. The administration of gold compounds leads to rapid distribution of gold throughout the body with a tendency for it to concentrate in areas of inflammation as well as in organs rich in reticuloendothelial elements $(43,44)$. Thus, tissue gold levels may provide a more meaningful estimation of both pharmacologically attainable and therapeutically effective gold concentrations. Mean synovial tissue gold concentrations of $21.1 \mu \mathrm{g} / \mathrm{g}$ of tissue (wet weight) have been reported in a group of 14 patients recently treated with a mean total dose of $1.84 \mathrm{~g}$ of gold (45). These findings are consistent with those reported in a patient who had received a total gold dose of 2,530 mg over a 5 -yr period and at postmortem examination had a mean synovial tissue gold concentration of 25 $\mu \mathrm{g} / \mathrm{g}$ wet weight (46). Although such estimations of tissue concentrations obtained by atomic absorption spectroscopy give no information about the physical state of the gold or its availability to cellular elements in the synovium, these data suggest that the maximal concentration of gold attainable at the relevant tissue site is equivalent to $42-50 \mu \mathrm{g} / \mathrm{ml}$ of GST.

GST was found to reversibly inhibit antigen- and mitogen-induced human lymphocyte proliferation. These findings are similar to results reported by others using PHA $(47,48)$ and allogeneic lymphocytes (48) as stimuli. Inhibition of responsiveness was dependent on the concentration of GST in the culture with significant suppression observed well within the range of serum and tissue levels found in patients treated with gold compounds. Inhibition of lymphocyte proliferation was dependent on the gold ion itself and not the sulfur-containing ligand inasmuch as GST and gold chloride were both inhibitory while TMA was not. Suppression of responsiveness could not be ascribed to cell death or an alteration in the kinetics of the in vitro response. Moreover, gold inhibition of responsiveness did not result from an interference with the binding or handling of mitogen by the cells. This was indicated by the observation that GST present only during an initial 24-h period of mitogen activation, but not during the subsequent $48 \mathrm{~h}$ of incubation, had no effect on the magnitude of the resultant proliferative response. This was supported by data obtained when the binding of radioiodinated mitogens to human PBM was studied. $100 \mu \mathrm{g} / \mathrm{ml}$ GST had no effect on the binding of either ${ }^{125}$ I-PHA or ${ }^{125}$ I-Con A measured after a 30-min incubation at $4^{\circ} \mathrm{C}$ (unpublished observation).

Gold compounds were found to act by specifically interfering with an early step in the inductive phase of lymphocyte activation, even before DNA synthesis began. Initiation of T-lymphocyte proliferation by the stimulating agents used requires the active participation of an accessory cell, which itself does not undergo a DNA synthetic response (17-22). In populations of human PBM, the monocyte subserves the requisite accessory cell function $(15,18,19,21,22)$. Therefore, experiments were carried out to determine whether one or the other participant in this two-cell responding unit was differentially affected by gold compounds. This question was first approached by investigating the inhibitory capacity of GST in cultures with various ratios of responding to accessory cells. An inverse relationship was noted between the degree of GST inhibition of the proliferative response to mitogens and the number of monocytes supporting that response. The data suggested that the action of GST on lymphocyte activation resulted not from inhibition of the potential responsiveness of the T-lymphocyte population, but rather from interference with the ability of the monocytes to serve as effective accessory cells in the initiation of such responses. Alternatively, monocytes merely could have acted in a protective capacity in these experiments, perhaps by internalizing GST and thus preventing its inhibitory effect on lymphocytes. To investigate this possibility, $100 \mu \mathrm{g} / \mathrm{ml}$ GST was incubated with PBM (containing $30 \%$ monocytes) or with medium alone for $24 \mathrm{~h}$ at $37^{\circ} \mathrm{C}$, and then tested at various concentrations for its capacity to inhibit lymphocyte proliferation. Preincubation of GST with PBM $\left(1 \times 10^{6} / \mathrm{ml}\right)$ did not diminish its subsequent inhibitory action on Con-A-induced lymphocyte DNA synthesis compared to GST similarly incubated in medium alone (unpublished observation). These data militate against the possibility that the function of monocytes in the cultures was to protect lymphocytes from the effects of gold by internalizing or otherwise inactivating GST.

Another indication of the cellular site of action of GST became apparent only after prolonged incubation of PBM with this gold compound. Thus, preincubation of PBM with GST for $72 \mathrm{~h}$ resulted in diminished mitogen responsiveness of these cells on subsequent challenge. This effect could be induced by prolonged exposure to concentrations of GST ( 25 or $50 \mu \mathrm{g} / \mathrm{ml}$ ) equivalent to those found in the synovial tissues of patients treated with gold compounds. Furthermore, this effect was irreversible inasmuch as the PBM exhibited diminished mitogen responsiveness even after removal of GST. The ability of fresh autologous monocytes to restore mitogen responsiveness to these populations indicated that prolonged exposure of this mixed PBM population to GST had not affected the intrinsic ability of the lymphocytes to respond but rather had altered the functional capacity of the monocytes to support such responses. This interpretation was confirmed by the observation that preincubation of purified monocytes with GST 
for $72 \mathrm{~h}$ rendered them deficient in their ability to support mitogen-induced T-lymphocyte proliferation on subsequent culture.

These studies indicate that a major action of gold compounds involves interference with the functional capability of $M \Phi$. This conclusion is consonant with a number of previous observations. First, microscope examination of rheumatoid synovial tissue obtained from patients treated with gold compounds has revealed a selective accumulation of gold particles in the lysosomes of the type A synovial cells and other macrophages of the synovium (29-31). Second, GST has been shown to be actively endocytosed in vitro by guinea pig peritoneal macrophages with resulting inhibition of their lysosomal enzyme activity (32). Finally, the phagocytic activity of macrophages in experimentally induced inflammatory exudates has been found to be suppressed in patients with rheumatoid arthritis receiving gold therapy as compared to untreated rheumatoid patients (33).

Mononuclear phagocytes play a central role in the initiation and maintenance of chronic inflammatory reactions. They not only function as effector cells in such responses (49), but also possess the unique capacity to interact with both $\mathrm{B}$ and $\mathrm{T}$ lymphocytes in the induction of cellular and humoral immune responses. Thus, antigen-induced proliferation and mediator synthesis by $\mathrm{T}$ lymphocytes require the active participation of $M \Phi(17,50)$. These accessory cells initially take up antigen and act to facilitate its functionally effective presentation to primed $\mathrm{T}$ lymphocytes (51). Similarly, macrophages play a critical role in the humoral response to many antigens by supporting the induction of antigen-specific helper $\mathrm{T}$ cells (52) and providing a focus for collaboration between helper $\mathrm{T}$ cells and $\mathrm{B}$ cells whose progeny secrete antibody $(53,54)$. In view of the critical role of mononuclear phagocytes in the induction of both cellular and humoral immune responses, pharmacologically induced interference with their function by gold compounds may, in part, explain the efficacy of these agents in reducing the chronic immunologically mediated inflammation of rheumatoid arthritis.

\section{ACKNOWLEDGMENTS}

We wish to thank Ms. Zora Dugan for her expert technical assistance and Ms. Terrie Harris and Ms. Bonita Walker for preparing the manuscript.

This work was supported by U. S. Public Health Service Progress grant AM-09989.

\section{REFERENCES}

1. Zvaifler, N. J. 1973. The immunopathology of joint inflammation in rheumatoid arthritis. Adv. Immunol. 16: 265-336.

2. Smiley, J. D., C. Sachs, and M. Ziff. 1968. In vitro synthesis of immunoglobulin by rheumatoid synovial membrain. J. Clin. Invest. 47: 624-632.
3. Loewi, G., J. Dorling, and A. Howard. 1974. Mononuclear cells from inflammatory joint effusions: Electron microscopic appearances and immunoglobulin synthesis. J. Rheum. 1: 34-44.

4. Zvaifler, N. J. 1971. Immunoreactants in rheumatoid synovial effusions. J. Exp. Med. 134: 276s-285s.

5. Frøland, S. S., J. B. Natvig, and G. Busby. 1973. Immunological characterization of lymphocytes in synovial fluid from patients with rheumatoid arthritis. Scand. J. Immunol. 2: 67-73.

6. Sheldon, P. J., M. Papamichail, and E. J. Holborow. 1974. Studies on synovial fluid lymphocytes in rheumatoid arthritis. Ann. Rheum. Dis. 33: 509-514.

7. Utsinger, P. D. 1975. Synovial fluid lymphocytes in rheumatoid arthritis. Arthritis Rheum. 18: 595-602.

8. van Boxel, J. A., and S. A. Paget. 1975. Predominantly T-cell infiltrate in rheumatoid synovial membranes. $N$. Engl. J. Med. 293: 517-520.

9. Loewi, G., E. M. Lance, and J. Reynolds. 1975. Study of lymphoid cells from inflamed synovial membranes. Ann. Rheum. Dis. 34: 524-528.

10. Research Subcommittee of the Empire Rheumatism Council. 1960. Gold therapy in rheumatoid arthritis. Report of a multi-centre controlled trial.Ann. Rheum. Dis. 19: 95-119.

11. Research Subcommittee of the Empire Rheumatism Council. 1961. Gold therapy in rheumatoid arthritis. Final report of a multicentre controlled trial. Ann. Rheum. Dis. 20: 315-334.

12. The Cooperating Clinics Committee of the American Rheumatism Association. 1973. A controlled trial of gold salt therapy in rheumatoid arthritis. Arthritis Rheum. 16: $353-358$.

13. Sigler, J. W., G. B. Bluhm, H. Duncan, J. T. Sharp, D. C. Ensign, and W. R. McCrum. 1974. A double-blind study. Gold salts in the treatment of rheumatoid arthritis. Ann. Intern. Med. 80: 21-26.

14. Greaves, M., G. Janossy, and M. Doenhoff. 1974. Selective triggering of human $\mathrm{T}$ and $\mathrm{B}$ lymphocytes in vitro by polyclonal mitogens. J. Exp. Med. 140: 1-18.

15. Lohrmann, H-P., L. Novikovs, and R. G. Graw, Jr. 1974. Cellular interactions in the proliferative response of human $\mathrm{T}$ and $\mathrm{B}$ lymphocytes to phytomitogens and allogeneic lymphocytes. J. Exp. Med. 139: 15531567.

16. Chess, L., R. P. MacDermott, and S. F. Schlossman. 1974. Immunologic functions of isolated human lymphocyte subpopulations. II. Antigen triggering of $T$ and $B$ cells in vitro. J. Immunol. 113: 1122-1127.

17. Waldron, J. A., R. G. Horn, and A. S. Rosenthal. 1974. Antigen-induced proliferation of guinea pig lymphocytes in vitro: Functional aspects of antigen handling by macrophages. J. Immunol. 112: 746-755.

18. Schecter, G. P., and W. McFarland. 1970. Interaction of lymphocytes and a radioresistant cell in PPD-stimulated human leukocyte cultures. J. Immunol. 105: 661-669.

19. Twomey, J. J., O. Sharkey, Jr., J. A. Brown, A. H. Laughter, and P. H. Jordan, Jr. 1970. Cellular requirements for the mitotic response in allogeneic mixed leukocyte cultures. J. Immunol. 104: 845-853.

20. Lipsky, P. E., J. J. Ellner, and A. S. Rosenthal. 1976. Phytohemagglutinin-induced proliferation of guinea pig thymus-derived lymphocytes. 1. Accessory cell dependence. J. Immunol. 116: 868-875.

21. Schmidtke, J. R., and S. Hatfield. 1976. Activation of purified human thymus-derived $(\mathrm{T})$ cells by mitogens. II. Monocyte-macrophage potentiation of mitogeninduced DNA synthesis. J. Immunol. 116: 357-362. 
22. Hedfors, E., G. Holm, and D. Pettersson. 1975. Activation of human peripheral blood lymphocytes by concanavalin A dependence of monocytes. Clin. Exp. Immunol. 22: 223-229.

23. Böyum, A. 1968. Isolation of mononuclear cells and granulocytes from human blood. Isolation of mononuclear cells by one centrifugation, and of granulocytes by combining centrifugation and sedimentation at $1 \mathrm{~g}$. Scand. J. Clin. Lab. Invest. Suppl. 21: 77-89.

24. Allison, A. C., and M. R. Young. 1964. Uptake of dyes and drugs by living cells in culture. Life Sci. 3: 14071414.

25. Jondal, M., G. Holm, and H. Wigzell. 1972. Surface markers on human $\mathrm{T}$ and $\mathrm{B}$ lymphocytes. I. A large population of lymphocytes forming nonimmune rosettes with sheep red blood cells. J. Exp. Med. 136: $207-215$.

26. Cunningham, B. A., J. L. Wang, G. R. Gunther, G. N. Reeke, Jr., and J. W. Becker. 1974. Molecular analysis of the initial events in mitogenesis. In Cellular Selection and Regulation in the Immune Response. G. M. Edelman, editor. Raven Press, New York. 177-197.

27. Bloom, B. R. 1971. In vitro approaches to the mechanism of cell-mediated immune reactions. Adv. Immunol. 13: $101-208$.

28. Yahara, I., and G. M. Edelman. 1972. Restriction of the mobility of lymphocyte immunoglobulin receptors by concanavalin A. Proc. Natl. Acad. Sci. U. S. A. 69: $608-612$.

29. Norton, W. L., D. C. Lewis, and M. Ziff. 1968. electrondense deposits following injection of gold sodium thiomalate and thiomalic acid. Arthritis Rheum. 11: 436-443.

30. Lewis, D. C., and M. Ziff. 1966. Intra-articular administration of gold salts. Arthritis Rheum. 9: 682-692.

31. Inoue, H. 1968. A light and electron microscopic study of the distribution of gold sodium thiomalate in the rheumatoid synovial membrane. Acta Med. Okayama. 22: $293-317$.

32. Persellin, R. H., and M. Ziff. 1966. The effect of gold salt on lysosomal enzymes of the peritoneal macrophage. Arthritis Rheum. 9: 57-65.

33. Jessop, J. D., B. Vernon-Roberts, and J. Harris. 1973. Effects of gold salts and prednisolone on inflammatory cells. 1. Phagocytic activity of macrophages and polymorphs in inflammatory exudates studied by a "skinwindow" technique in rheumatoid and control patients. Ann. Rheum. Dis. 32: 294-300.

34. Vermon-Roberts, B., J. D. Jessop, and J. Doré. 1973. Effects of gold salts and prednisolone on inflammatory cells. II. Suppression of inflammation and phagocytosis in the rat. Ann. Rheum. Dis. 32: 301-307.

35. Szilágyi, T., S. Toth, L. Muszbek, G. Lévai, and J. Laczkó. 1968. The effect of gold treatment on local Shwartzman phenomenon. Acta Microbiol. Acad. Sci. Hung. 15: 331-336.

36. Waltz, D. T. M. J. Dimartino, and B. M. Sutton. 1974. Design and laboratory evaluation of gold compounds as antiinflammatory agents. In Antiinflammatory Agents: Chemistry and Pharmacology, R. A. Scherrer and M. W. Whitehouse, editors. Academic Press, New York. 209244.

37. Lorber, A., R. L. Cohen, C. C. Chang, and H. E. Anderson. 1968. Gold determination in biological fluids by atomic absorption spectrophotometry: application to chryso- therapy in rheumatoid arthritis patients. Arthritis Rheum. 11: $170-177$.

38. Mascarenhas, B. R., J. L. Granda, and R. H. Freyberg. 1972. Gold metabolism in patients with rheumatoid arthritis treated with gold compounds-reinvestigated. Arthritis Rheum. 15: 391-402.

39. Jessop, J. D., and R. G. S. Johns. 1973. Serum gold determinations in patients with rheumatoid arthritis receiving sodium aurothiomalate. Ann. Rheum. Dis. 32: 228-232.

40. Rubinstein, H. M., and A. A. Dietz. 1973. Serum gold. II. Levels in rheumatoid arthritis. Ann. Rheum. Dis. 32 : 128-132.

41. Billings, R., R. Grahame, V. Marks, P. J. Wood, and A. Taylor. 1975. Blood and urine gold levels during chrysotherapy for rheumatoid arthritis. Rheumatol. Rehabil. 14: 13-18.

42. Gerber, R. C., H. E. Paulus, R. Bluestone, and C. M. Pearson. 1972. Clinical response to serum gold levels in chrysotherapy. Lack of correlation. Ann. Rheum. Dis. 31: $308-310$.

43. Bertrand, J. J., H. Waine, C. A. Tobias. 1948. Distribution of gold in the animal body in relation to arthritis. J. Lab. Clin. Med. 33: 1133-1138.

44. Lawrence, J. S. 1961. Studies with radioactive gold. Ann. Rheum. Dis. 20: 341-352.

45. Grahame, R., R. Billings, M. Laurence, V. Marks, and P. J. Wood. 1974. Tissue gold levels after chrysotherapy. Ann. Rheum. Dis. 33: 536-539.

46. Gottlieb, N. L., P. M. Smith, and E. M. Smith. 1972. Tissue gold concentration in a rheumatoid arthritic receiving chrysotherapy. Arthritis Rheum. 15: 16-22.

47. Cahill, R. N. P. 1971. Effect of sodium aurothiomalate "Myocrisin" on DNA synthesis in phytohaemagglutininstimulated cultures of sheep lymphocytes. Experientia (Basel). 27: 913-914.

48. Harth, M., C. Stiller, D. McGirr, J. Evans, and N. Sinclair 1976. Effects of sodium aurothiomalate (SATM) on lymphocyte responses in normal man and patients with rheumatoid arthritis (RA). J. Rheum. 3: 100. (Abstr.)

49. Page, R. C., P. Davies, and A. C. Allison. 1974. Participation of mononuclear phagocytes in chronic inflammatory diseases. J. Reticuloendothel. Soc. 15: 413-438.

50. Nelson, R. D., and R. W. Leu. 1975. Macrophage requirement for production of guinea pig migration inhibitory factor (MIF) in vitro. J. Immunol. 114: 606-609.

51. Rosenthal, A. S., J. T. Blake, J. J. Ellner, D. K. Greineder, and P. E. Lipsky. 1975. The role of macrophages in Tlymphocyte antigen recognition. In Immune Recognition. A. S. Rosenthal, editor. Academic Press, Inc., New York. 539-554

52. Erb, P., and M. Feldmann. 1975. The role of macrophages in the generation of T-helper cells. 1 . The requirement for macrophages in helper cell induction and characteristics of macrophage-T cell interaction. Cell. Immunol. 19: 356-367.

53. Feldmann, M. 1972. Cell interactions in the immune response in vitro. II. The requirement for macrophages in lymphoid cell collaboration. J. Exp. Med. 135: 10491058.

54. Katz, D. H., and E. R. Unanue. 1973. Critical role of determinant presentation in the induction of specific responses in immunocompetent lymphocytes. $J$. Exp. Med. 137: 967-990. 